\title{
Vybrané aspekty reportovaných výsledků plánů povodí
}

\section{HANA PRCHALOVÁ, SILVIE SEMERÁDOVÁ, PETR VYSKOČ}

Klíčová slova: Rámcová směrnice o vodách - plán povodí - reporting - vodní útvar - programy opatření - analýza vlivů a dopadů

\section{SOUHRN}

Zpracování dat pro reporting plánů povodí v ČR umožňuje nejen získat podrobné statistiky výsledků, ale také pochopit souvislosti mezi dílčími výsledky a jejich význam pro dosažení stanovených cílů. Článek je zaměřen na vybrané souvislosti a konzistence výsledků, které při zpracování plánů nepatřily k prioritním, at’ už se jednalo o stanovení užívání pro silně ovlivněné vodní útvary, harmonizace výsledků hodnocení biologických složek a všeobecných fyzikálně-chemických ukazatelů ekologického stavu, nebo určení antropogenních vlivů, způsobujících nedosažení dobrého stavu a rozdělení nákladů na opatření. Přesto se ukazuje, že tyto souvislosti nelze podceňovat, pokud mají být vynaložené prostředky a čas nutný na jejich zpracování dostatečně efektivní.

\section{ÚVOD}

I když hlavním důvodem reportingu plánů povodí byla povinnost ČR vůči Evropské komisi, přesto výsledky reportingu mohou být užitečné i pro odbornou veřejnost včetně zpracovatelů plánů. Rozsah reportingu je určen směrným dokumentem [1], na rozdíl od prvního cyklu plánů (první cyklus plánů probíhal v letech 2003-2009, aktualizace plánů pak v druhém cyklu 2010-2016) se sice jeho obsah rozširíil, ale je logicky provázaný a umožňuje lepší přehled o kvalitě plánů z hlediska dosažení environmentálních cílů. Následující přehled jednak navazuje na souhrnné údaje v předchozím článku a jednak si také všímá vybraných mezer či nekonzistencí, které se při reportingu objevily.

\section{SILNĚ OVLIVNĚNÉ ÚTVARY POVRCHOVÝCH VOD}

Součástí plánů byla identifikace silně ovlivněných útvarů (heavily modified water bodies, HMWBs), což jsou útvary, kde kvưli existujícím fyzikálním změnám z důvodu nadřazeného veřejného zájmu jsou požadavky na dosažení environmentálních cílů v určitém směru mírnější - mají dosáhnout dobrý ekologický potenciál, nikoliv ekologický stav. Zároveň se ale předpokládá, že k jejich identifikaci existuje dobrý důvod - a sice nějaké významné uživání vod, které je zásadní pro lidskou společnost a které nelze snadno nahradit jiným způsobem. Proto je jedním z požadavků reportingu určení typu užívání pro každý silně ovlivněný útvar.

Silně ovlivněné útvary mohou patřit do kategorie jezero nebo do kategorie řeka. Všechny nádrže a rybníky, vymezené v ČR jako samostatný útvar, patří automaticky $k$ silně ovlivněným (popř. umělým) útvarům - v ČR neexistuje prirozené jezero, které by mělo plochu alespoň 0,5 km², což je minimální velikost samostatného útvaru stojatých vod. Zároveň všechny nádrže byly vybudovány pro nějaký účel a nepředpokládá se, že by se měly zlikvidovat (což by byl jediný způsob, jak je vrátit do kategorie přirozených vodních útvarů). Počet identifikovaných silně ovlivněných útvarů kategorie jezero byl tedy predem určen a zbývalo k nim přiřadit užívání. Proti tomu identifikace silně ovlivněných útvarů kategorie řeka předpokládá nejprve zjištění významného hydromorfologického ovlivnění a dále nalezení nutného uživání neumožňujícího návrh opatření k dosažení dobrého stavu. $V$ druhém cyklu byla aplikována metodika vymezení silně ovlivněných útvarů [2], která definovala užívání v ČR, odůvodňující identifikaci silně ovlivněných útvarů kategorie řeka. Jednalo se o tato uznatelná užívání: - zásobování pitnou vodou,

- závlahy,

— výroba elektrické energie $v$ rámci vodních útvarů v kategorii jezero a v rámci vodních útvarů v kategorii řeka $v$ prípadě instalovaného výkonu nad $2 \mathrm{MW}$ (vztaženo k jediné překážce na toku),

- rekreace v rámci vodních útvarů v kategorii jezero,

- ochrana intravilánu před povodněmi,

— trvalé rozvojové činnosti člověka: chov ryb v rámci vodních útvarů v kategorii jezero a odběry vod pro průmysl,

- plavba v rámci vodních útvarů v kategorii řeka, které jsou vymezeny jako vodní cesty dopravně významné využivané,

— širší okolí, tzn., že ve zvláštních prípadech je třeba zvažovat přírodní, kulturní nebo historické hodnoty (např. archeologické naleziště, technická památka, chráněné území s výskytem ohrožených druhů organismů), tyto případy je nutné posuzovat individuálně.

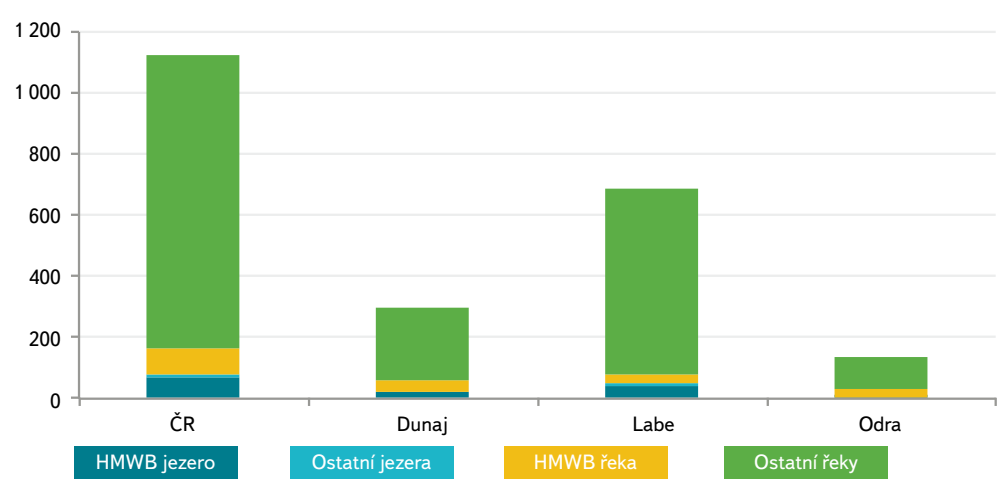

Obr. 1. Podíl vymezených silně ovlivněných útvarů kategorie jezero a řeka; zdroj dat: WFD Reporting 2016 [3]

Fig. 1. Proportion of delineated heavily modified surface water bodies category lake and river; data source: WFD Reporting 2016 [3] 


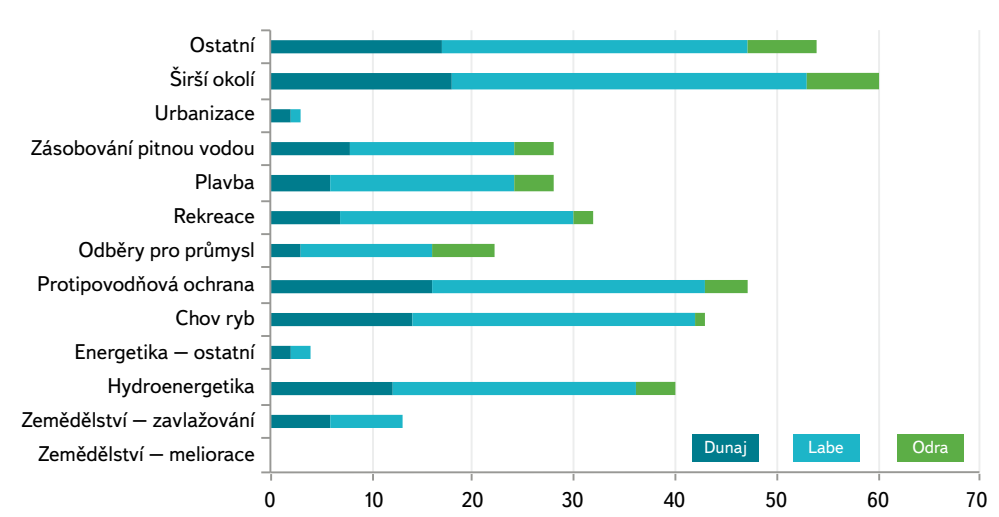

Obr. 2. Typy uživání silně ovlivněných útvarů kategorie jezero; zdroj dat: WFD Reporting 2016 Fig. 2. Uses of heavily modified water bodies category lake; data source: WFD Reporting 2016

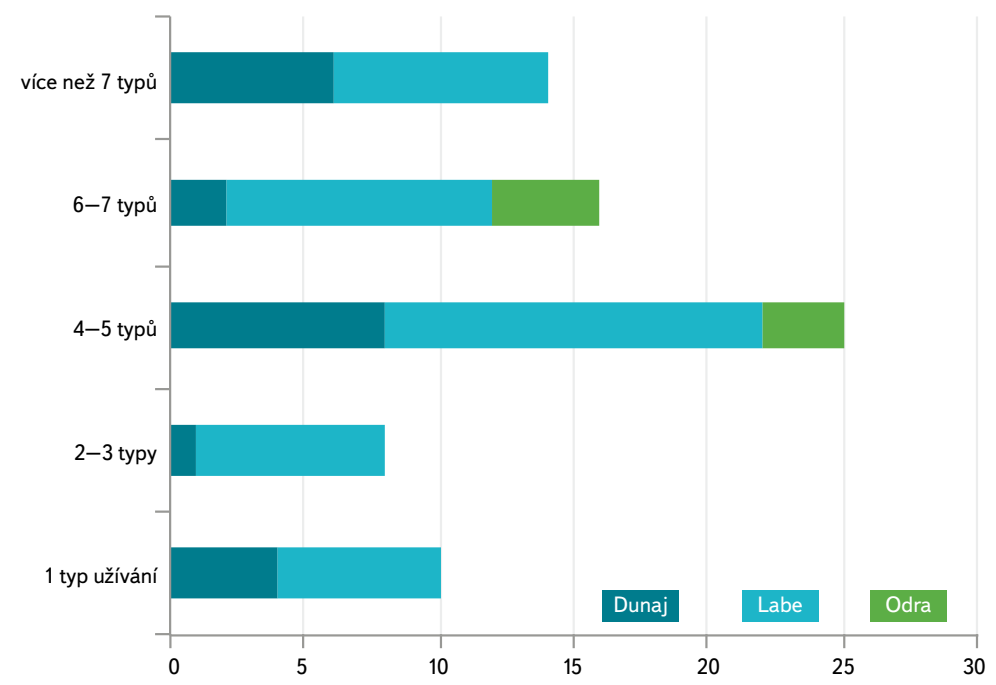

Obr. 3. Počet typů užívání silně ovlivněných útvarů kategorie jezero; zdroj dat: WFD Reporting 2016

Fig. 3. Number of uses of heavily modified water bodies category lake; data source: WFD Reporting 2016

Při identifikaci HMWB u řek tedy záleželo mimo jiné na dostatku informací o hydromorfologických změnách a o známém užívání. Ve výsledku byl podíl silně ovlivněných útvarů kategorie řeka v národních povodích různý (obr. 1). Nejvíce je jich v povodí Odry - 16,8 \%, kde bylo také nejúplnější hydromorfologické mapování, pak v povodí Dunaje - 12,6 \% a nejméně v povodí Labe - $5 \%$. Rozdíly Ize kromě množství hydromorfologických dat přičíst odlišným přistupům jednotlivých podniků povodí, kdy hlavně uznatelné uživání pravděpodobně nehrálo při identifikaci HMWB tak významnou roli.

Neméně zajímavou informací jsou zjištěné typy a počty užívání, opět členěné na nádrže, rybníky a řeky (obr. 2-5). Zatímco u nádrží a rybníků je počet užívání na jeden útvar nejčastěji 4 nebo 5 (obr. 3) a nejčastějšími typy užívání je širší okolí, ostatní uživání (hlavně nadlepšování průtoků), protipovodňová ochrana, chov ryb a hydroenergetika (obr. 2); pro řeky byl většinou určen jen jeden typ užívání - protipovodňová ochrana (obr. 4 a 5). Stejně tak se liší nejčastější typy užívání podle národních povodí. Širší okolí a ostatní jsou sice nejčastější ve všech nádržích a rybnících, ale pro Odru jsou třetí v pořadí odběry pro průmysl, zatímco pro Labe a Dunaj protipovodňová ochrana a chov ryb a na Labi je také velmi významná hydroenergetika. U silně ovlivněných řek je na Odře významná pouze protipovodňová ochrana, na Dunaji jsou to ale také

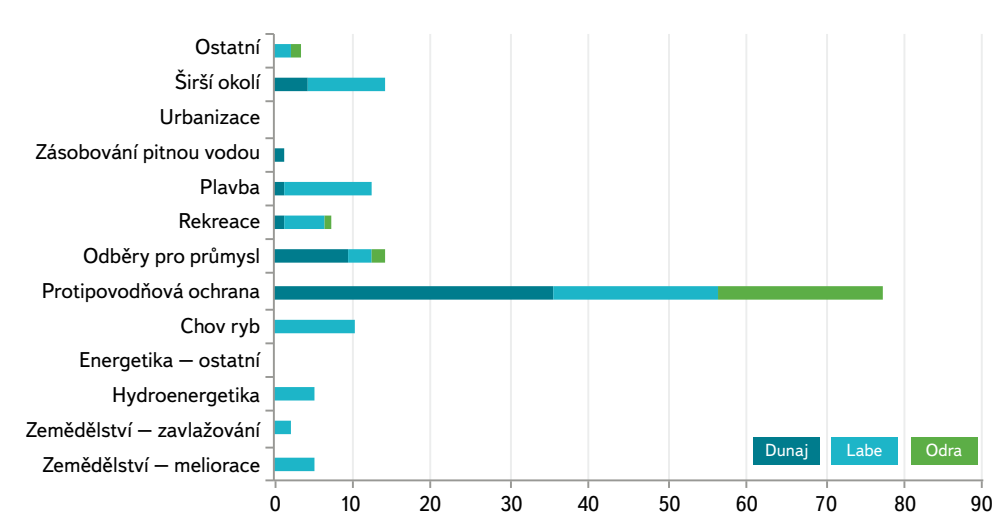

Obr. 4. Typy užívání silně ovlivněných útvarů kategorie řeka; zdroj dat: WFD Reporting 2016 Fig. 4. Uses of heavily modified water bodies category river; data source: WFD Reporting 2016

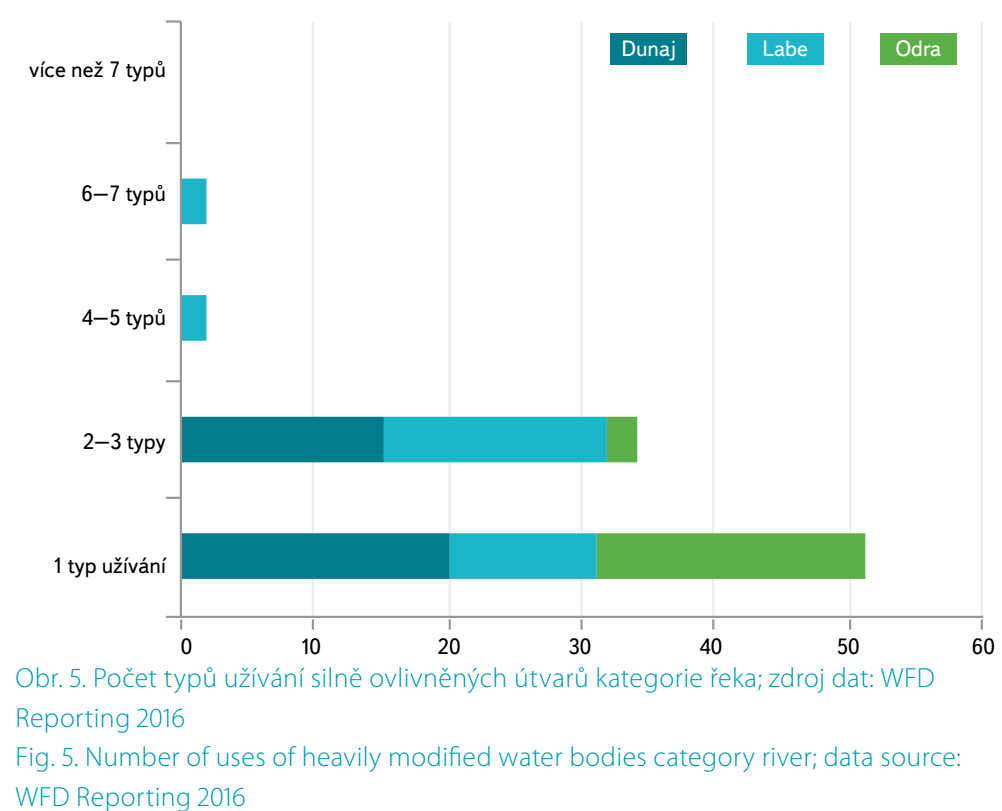

odběry pro průmysl a na Labi plavba, širší okolí a chov ryb. Zásobování pitnou vodou je pro kategorii jezero stejně četným užíváním jako plavba (38 \%), i když se vyloučí rybníky, stále je to pouze $50 \%$.

Zatímco vyšší počet užívání útvarů kategorie jezero většinou umožňuje dostatek argumentů pro jejich zařazení do silně ovlivněných útvarů, u řek bude pravděpodobně obtížné pro některé útvary s významnými hydromorfologickými vlivy obhájit jejich zařazení do HMWB, nebot jejich užívání nepatří do "uznatelných". Proto bude bud” nutné zvážit nově definované užívání, které ale musí být zároveň obhajitelné pred Evropskou komisí, nebo př́slušné útvary označit za přirozené a navrhnout v nich opatření k dosažení dobrého ekologického stavu. 


\section{VYHODNOCENÍ EKOLOGICKÉHO STAVU NEBO POTENCIÁLU PRO BIOLOGICKÉ SLOŽKY VE VZTAHU K VŠEOBECNÝM FYZIKÁLNĚ-CHEMICKÝM UKAZATELŮM}

Ekologický stav se hodnotí podle výsledků biologických a fyzikálně-chemických složek, popř. hydromorfologické složky. Ačkoliv biologické složky jsou zásadní, výsledný stav je určen horším výsledkem biologické a fyzikálně-chemické složky, proto je důležité, aby nastavení „podpůrných“ ukazatelů odpovídalo požadavkům biologických složek (tj. makrozoobentosu, fytobentosu, fytoplanktonu, makrofyt a ryb). Fyzikálně-chemická složka se rozlišuje na všeobecné ukazatele, které musí obsahovat ukazatele, které reprezentují tepelné a kyslíkové poměry, slanost, acidobasický stav a živinové podmínky, a na specifické znečištující látky. Zatímco vztah mezi specifickými znečištujícími látkami a biologickými složkami může být volnější, nastavení rozmezí všeobecných ukazatelů (popř. hydromorfologických ukazatelů) musí být takové, aby se zabezpečily funkce typově specifických ekosystémů.

Jak již vyplývá ze souhrnných údajů předchozího článku, nejčastějším důvodem nedosažení dobrého ekologického stavu jsou z biologických ukazatelů makrozoobentos a fytobentos, dále znečištění specifickými látkami a nedosažení limitů dobrého stavu pro nutrienty. Pokud se ale udělají statistiky pro celé skupiny složek, jsou nejčastějšími nevyhovujícími biologické složky a všeobecné fyzikálně-chemické ukazatele (obr. 6).

$\checkmark$ druhém cyklu byly nejprve navrženy relativně prísné limity všeobecných ukazatelů, když se ale ukázalo, že počet nevyhovujících útvarů by byl značně vysoký, byly tyto limity poněkud zmírněny. V současné době se na evropské úrovni uvažuje o harmonizaci limitů pro nutrienty s požadavky na biologické složky. V současné době se i u vnitrozemských států koordinují požadavky na ochranu mořského prostředía ČR již prijijimá některé konkrétní závazky na snížení látkového odtoku nutrientů (zatím pro povodí Labe [4], ale pravděpodobně se bude stupňovat tlak na kvantifikaci snížení odtoku nutrientů i v ostatních dvou povodích). V druhém cyklu plánů také nastávala situace, že biologická složka byla vyhodnocená jako horší než dobrá, ale pro všeobecné ukazatele jako nevyhovující (a hydromorfologická složka se nehodnotila vůbec), tudíz nešlo navrhnout opatření pro dosažení dobrého stavu. I v ČR pravděpodobně bude muset dojít ke zpřísnění limitů všeobecných ukazatelů, proto je znalost vztahů mezi všeobecnými ukazateli, hydromorfologickou složkou a biologickými složkami klíčová. Na základě výsledků z druhého cyklu plánů Ize vysledovat

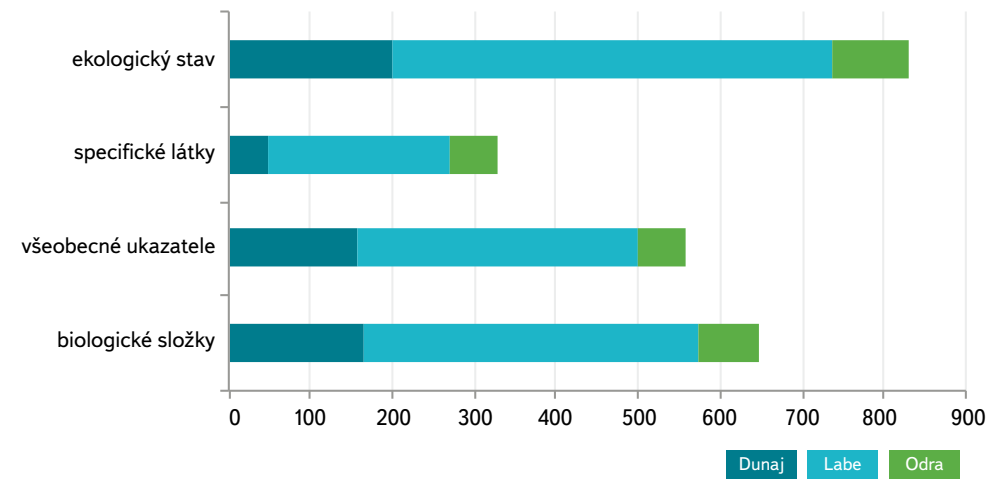

Obr. 6. Počet útvarů kategorie řeka s nevyhovujícím ekologickým stavem nebo potenciálem a počet nevyhovujících útvarů pro skupiny složek nebo ukazatelů; zdroj dat: WFD Reporting 2016

Fig. 6. Number of water bodies category river in less than good ecological status or potential and number of failing water bodies for groups of elements or pollutants; data source: WFD Reporting 2016 pravděpodobnou závislost mezi výsledky všeobecných fyzikálně-chemických ukazatelů a makrozoobentosem a fytobentosem, tj. nejčastěji sledované a hodnocené biologické složky (obr. 7 a 8). I když počet nevyhovujících útvarů se pro makrozoobentos a fytobentos liší, podíl útvarů s nevyhovujícími výsledky všeobecných fyzikálně-chemických ukazatelů je obdobný - 70 \% v celé ČR. Je otázka, jestli zbývajících 30 \% útvarů je skutečně vyhovujících pro všeobecné ukazatele (a důvodem nedosažení dobrého ekologického stavu je hydromorfologická složka), anebo je hodnocení ovlivněno př́liš mírnými limity, popř. neadekvátní typologií. Stejně tak nelze úplně vyloučit ani př́liš př́isné hodnocení biologické složky - ta ale prochází celoevropskou interkalibrací. Prezentované propojení je tedy pouze orientační, nezohledňuje typy útvarů a pouze naznačuje směr, kterým by se harmonizace mohla ubírat.

Ve třetím cyklu by tedy měly být navrženy a harmonizovány limity ekologického stavu pro všeobecné fyzikálně-chemické ukazatele s relevantními biologickými složkami. Zároveň by měl být do výzkumných programů co nejdřive zařazen skutečný dopad fyzikálně-chemických ukazatelů a hydromorfologických ovlivnění na ekologický stav útvarů povrchových vod.

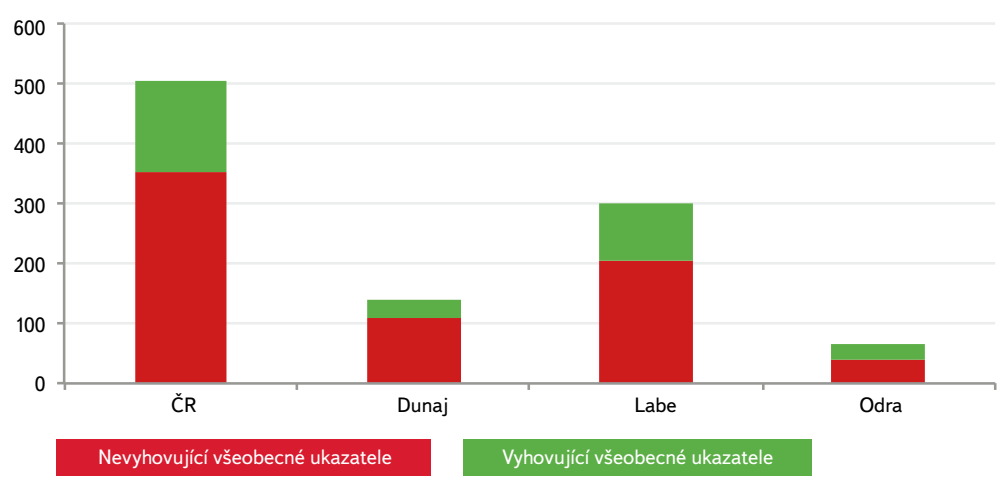

Obr. 7. Počet útvarů kategorie řeka s nevyhovujícím makrozoobentosem rozlišených podle výsledků všeobecných fyzikálně-chemických ukazatelů; zdroj dat: WFD Reporting 2016

Fig. 7. Number of water bodies category river in less than good ecological status or potential for Benthic invertebrates by results of general physico-chemical pollutants; data source: WFD Reporting 2016

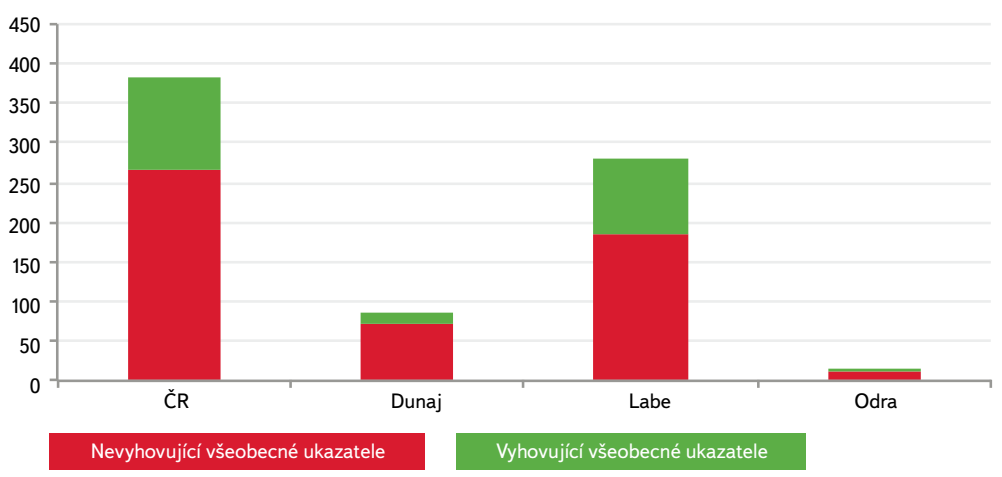

Obr. 8. Počet útvarů kategorie řeka s nevyhovujícím fytobentosem rozlišených podle výsledků všeobecných fyzikálně-chemických ukazatelů; zdroj dat: WFD Reporting 2016 Fig. 8. Number of water bodies category river in less than good ecological status or potential for Phytobenthos by results of general physico-chemical pollutants; data source: WFD Reporting 2016 


\section{VÝZNAMNÉ VLIVY PRO NEDOSAŽENÍ DOBRÉHO STAVU ÚTVARŮ A UPLATNĚNÉ VÝJIMKY}

Významné typy vlivů pro povrchové a podzemní vody (podrobné vysvětlení je uvedeno v předchozím souhrnném článku) byly reportovány dvojmo - jednou pro každý útvar (kde mohly být i některé vlivy, u kterých nebylo prokázáno, že způsobují nedosažení dobrého stavu) a po druhé ke každé složce ekologického stavu nebo ukazateli, kvůli kterému je nutné žádat o výjimku (tj. kde nebylo dosaženo dobrého stavu k roku 2015). V ČR byly posouzeny současné programy opatření, a pokud na jejich základě nebylo možné předpokládat dosažení dobrého stavu do konce roku 2027, byla navržena výjimka "nižší cíle", nebot podle Rámcové směrnice o vodě [5] je nutné dosáhnout dobrého stavu útvarů nejpozději v roce 2027. V případě, že bylo možné předpokládat dosažení dobrého stavu do konce roku 2027, bylo jako typ výjimky použito prodloužení Ihůty. Zároveň se předpokládá, že posouzení navrhovaných opatření proběhne i ve třetím cyklu a navržené výjimky se zpřesní. Zároveň Evropská komise oznámila, že „prodloužení lhưt" bude moci být použito i pro opatření, která zajistí dosažení dobrého stavu po roce 2027, takže se dá předpokládat, že počet výjimek „nižší cíle" se významně sníží.

Podíl významných vlivů, kvůli kterým je nutné požadovat výjimku pro ekologický stav či potenciál útvarů povrchových vod (obr. 9), je obdobný jako podíl všech významných vlivů v předchozím článku. Hlavní rozdíl je v podílu atmosférické depozice, který je pro ekologický stav výrazně nižší - pouze $10 \%$ proti $22 \%$, tzn., že atmosférická depozice častěji způsobuje nedosažení dobrého chemického stavu povrchových vod. To je ostatně dobře vidět na obr. 10-13, kde jsou uvedeny významné vlivy pro několik nejčastěji nevyhovujících ukazatelů chemického stavu útvarů povrchových vod. Pro polyaromatické uhlovodíky (obr. 10-12) je nejvýznamnějším vlivem atmosférická depozice, minoritní jsou průmyslové odpadní vody a stará kontaminovaná místa, pro značný počet útvarů se však vliv způsobující nedosažení dobrého stavu nepodařilo určit. Pro nikl (obr. 13) má většina útvarů neznámý vliv a jako další minoritní vliv se objevují dưlní vody.

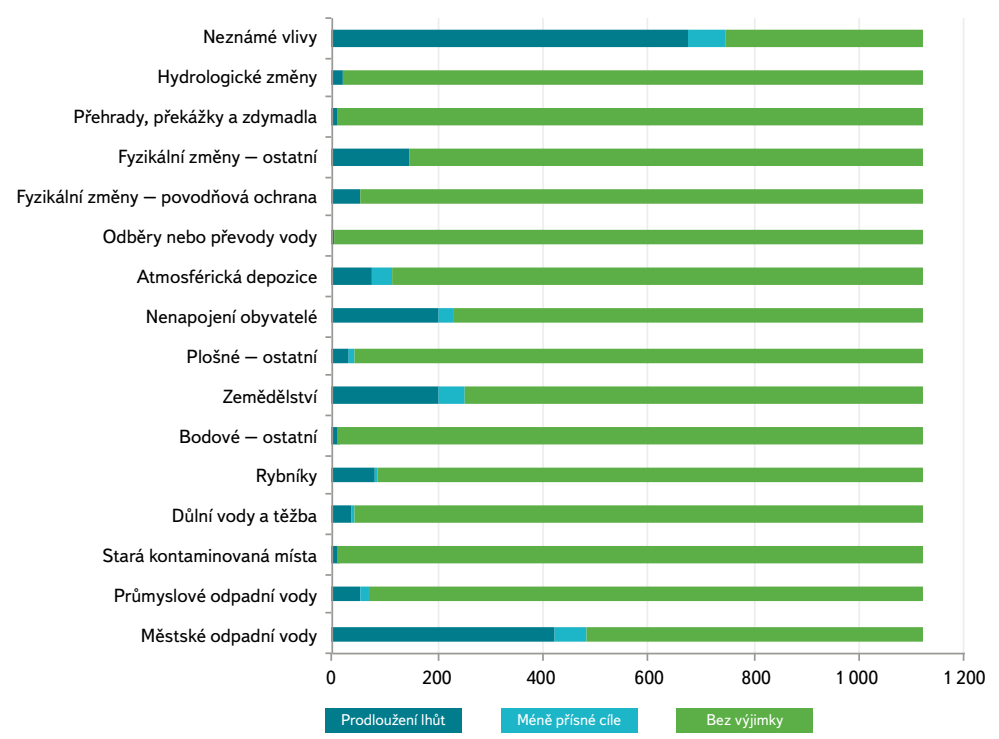

Obr. 9. Významné vlivy pro výjimky jednotlivých složek ekologického stavu nebo potenciálu útvarů povrchových vod; zdroj dat: WFD Reporting 2016

Fig. 9. Significant pressures of quality elements of ecological status/potential of surface water bodies; data source: WFD Reporting 2016

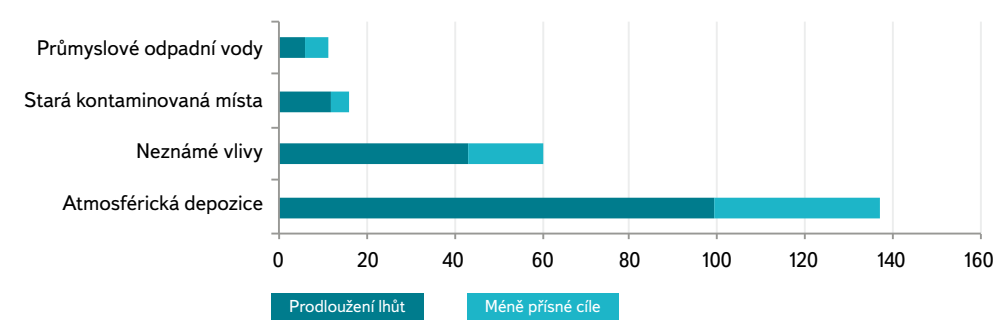

Obr. 10. Významné vlivy pro výjimky benzo(g,h,i)perylenu (chemický stav útvarů povrchových vod); zdroj dat: WFD Reporting 2016

Fig. 10. Significant pressures of benzo(g,h,i)perylene (surface water chemical status); data source: WFD Reporting 2016

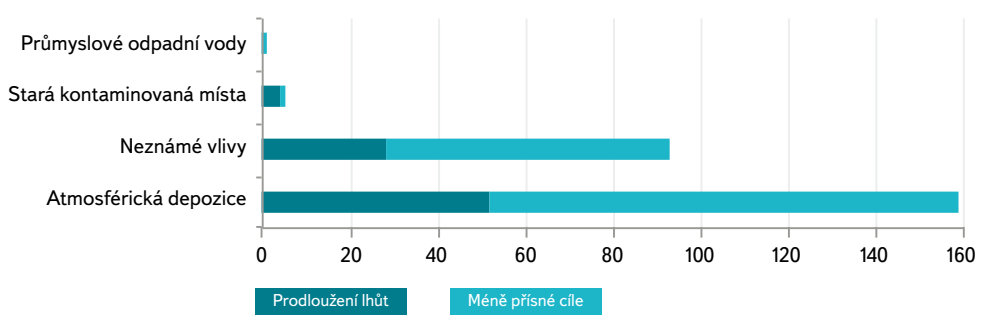

Obr. 11. Významné vlivy pro výjimky fluorantenu (chemický stav útvarů povrchových vod); zdroj dat: WFD Reporting 2016

Fig. 11. Significant pressures of fluoranthene (surface water chemical status); data source: WFD Reporting 2016

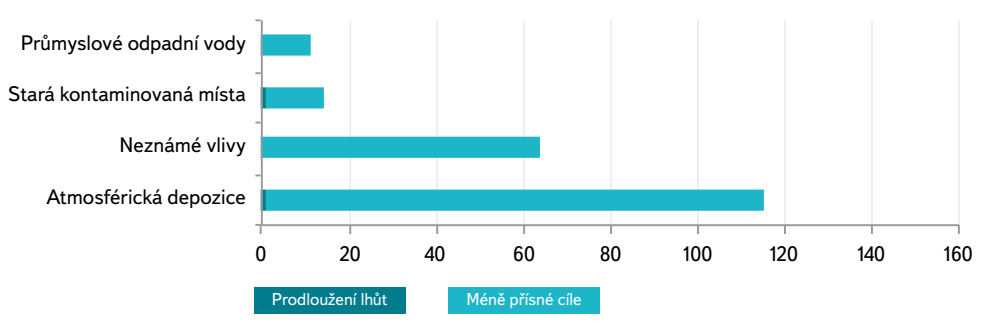

Obr. 12. Významné vlivy pro výjimky benzo(a)pyrenu (chemický stav útvarů povrchových vod); zdroj dat: WFD Reporting 2016

Fig. 12. Significant pressures of benzo(a)pyrene (surface water chemical status); data source: WFD Reporting 2016

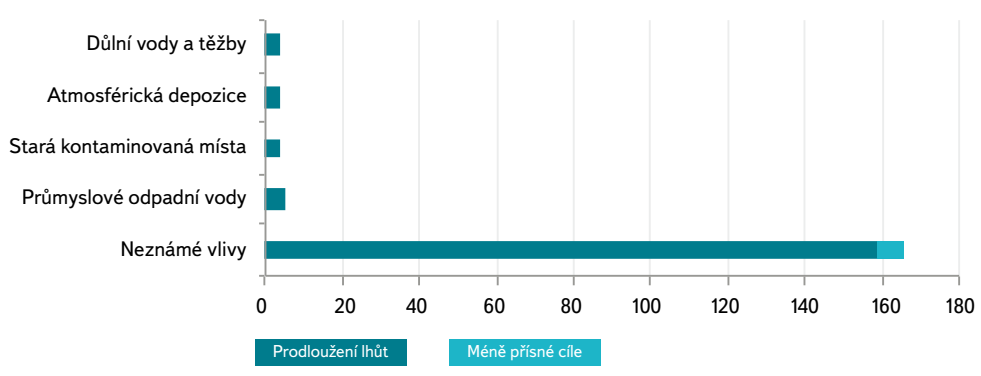

Obr. 13. Významné vlivy pro výjimky niklu (chemický stav útvarů povrchových vod); zdroj dat: WFD Reporting 2016

Fig. 13. Significant pressures of nickel (surface water chemical status); data source: WFD Reporting 2016 


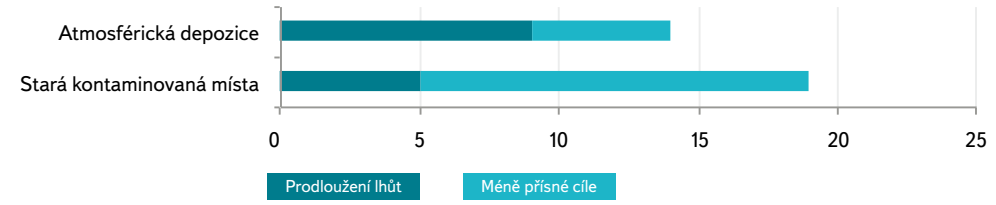

Obr. 14. Významné vlivy pro výjimky kadmia (chemický stav podzemních vod); zdroj dat WFD Reporting 2016

Fig. 14. Significant pressures of cadmium (groundwater chemical status); data source: WFD Reporting 2016

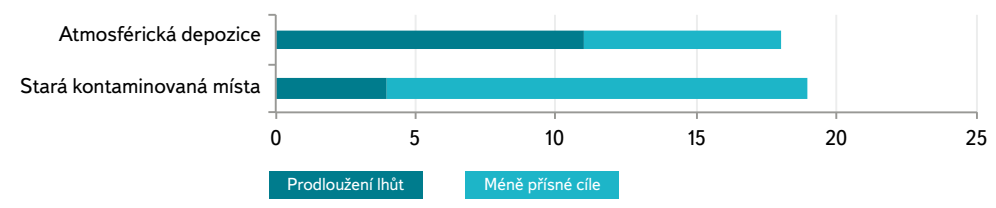

Obr. 15. Významné vlivy pro výjimky indeno(1,2,3-cd)pyrenu (chemický stav podzemních vod); zdroj dat: WFD Reporting 2016

Fig. 15. Significant pressures of indeno(1,2,3-cd)pyrene (groundwater chemical status); data source: WFD Reporting 2016

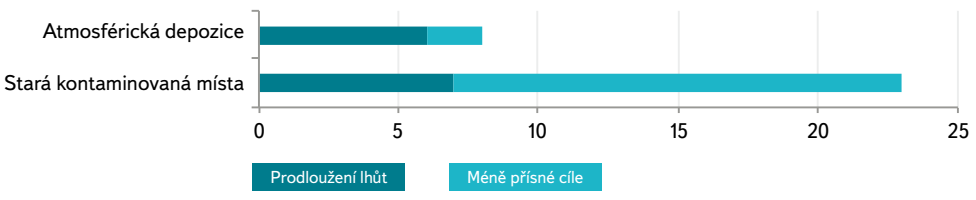

Obr. 16. Významné vlivy pro výjimky olova (chemický stav podzemních vod); zdroj dat: WFD Reporting 2016

Fig. 16. Significant pressures of lead (groundwater chemical status); data source: WFD Reporting 2016

Pro kvantitativní stav podzemní vody jsou významným vlivem odběry (hlavně pro zásobování pitnou vodou) a $v$ jednom případě i bývalá těžba uranu. Pro chemický stav podzemních vod jsou nejčastěji nevyhovující dusičnany a pesticidy, pro něž je významným vlivem plošné znečištění ze zemědělství, k dalším nejčastěji nevyhovujícím ukazatelům patří těžké kovy (kadmium a olovo) a některé polyaromatické uhlovodíky. Významnými vlivy všech těchto znečištujících látek jsou stará kontaminovaná místa a atmosférická depozice (obr. 14-16, jedná se o počet útvarů podzemních vod), přičemž pro olovo jsou stará kontaminovaná místa významnější - důvodem bude asi fakt, že množství olova v atmosférické depozici je v současné době výrazně nižší.

Pro dosažení cílů RSV bude nutné zpřesnit znalosti o antropogenních vlivech, které způsobují nedosažení dobrého stavu - jednak ověřit již identifikované významné vlivy, důsledně je provázat s ukazateli a složkami stavu a snížení počtu neznámých vlivů na minimum. K tomu bude zřejmě nutné zpracovat nové metodiky identifikace významných vlivů, popř. prověřit a upravit již existující postupy. Zároveň je důležité propojit sektorové politiky (ať už se jedná o zemědělství, průmysl či dopravu), aby se např. při opatřeních pro zlepšení stavu ovzduší zároveň respektovaly i požadavky RSV týkající se atmosférické depozice.

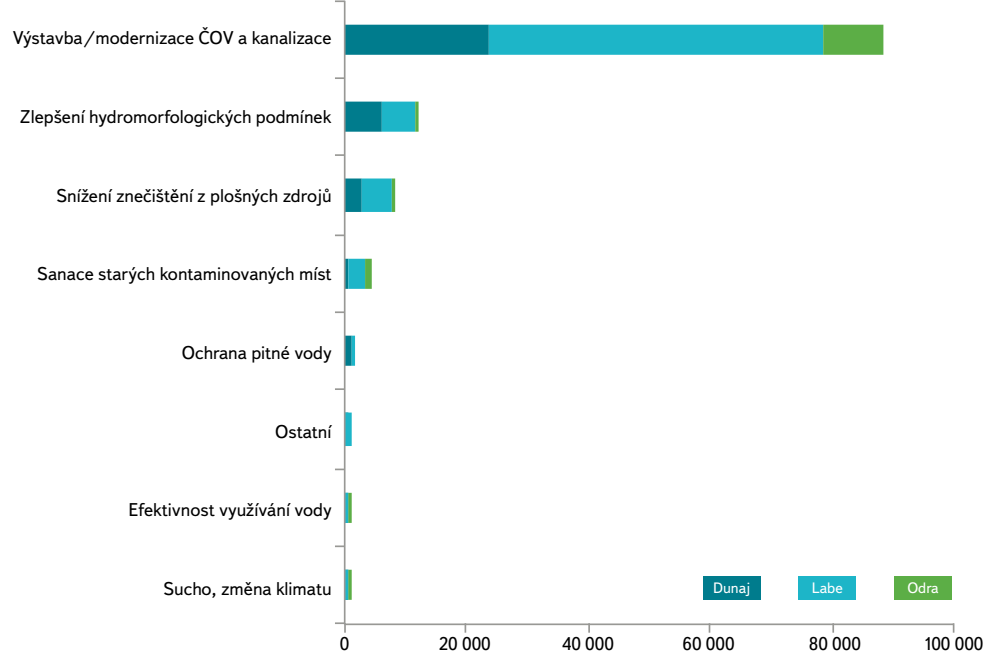

Obr. 17. Náklady na opatření v druhém cyklu plánů v tisících korunách; zdroj dat: Národní plány [7-9]

Fig. 17. Cost of measures in the second cycle in thousands of Czech crownes; data source: National plans [7-9]

\section{OPATŘENÍ K DOSAŽENÍ DOBRÉHO STAVU}

Z plánů povodí vyplývá, že nejvíce opatření je navrhováno na stokovou sít a čištění městských odpadních vod, zlepšení hydromorfologických podmínek a sanace starých kontaminovaných míst. Následující graf (obr. 17) ukazuje náklady na opatření v druhém cyklu. Náklady na stokovou sít a ČOV jsou zdaleka nejvyšší, následuje zlepšení hydromorfologických podmínek a snížení znečištění z plošných zdrojů. Z toho Ize usuzovat, že se ČR (stejně jako velká část evropských zemí) zaměřuje hlavně na tzv. základní opatření, vycházející ze starších směrnic o vodě, hlavně ale na požadavky směrnice o čištění městských odpadních vod [6]. To samožrejmě souvisí také s tím, že koncept vliv - stav dopad - odezva je nejlépe kvantifikovatelný a účinnost navrhovaných opatření vcelku známá. To však bylo vcelku obhajitelné v prvním cyklu plánů, v současné době se od členských zemí očekává identifikace "mezer" a návrh doplňkových opatření. Pokud tedy má ČR dosáhnout dobrého stavu u více útvarů, bude nutné zlepšit znalost vlivů způsobujících nedosažení dobrého stavu možných opatření a jejich efektivity a podle toho zaměřit nová navrhovaná opatření.

\section{ZÁVĚRY}

Data, připravená pro reporting, ukazují některé významné souvislosti, na které nebyl kladen dostatečný dưraz, at’ už se jedná o identifikaci silně ovlivněných útvarů v souvislosti s jejich užíváním, harmonizace limitů biologických složek a všeobecných fyzikálně-chemických ukazatelů, identifikace antropogenních vlivů, způsobujících nedosažení dobrého stavu a následných navržených opatření. Ukazuje se, že při zpracování plánů se poměrně pečlivě řeší jednotlivé aspekty, ale občas dochází k přehližení jejich souvislostí. Za nejvýznamnější krok Ize považovat provázanost důsledného určení významných vlivů (tj. nahradit vysoký podíl neznámých vlivů) a navržených opatření, včetně zajištění finančních prostředků, ale také harmonizaci biologických složek s všeobecnými ukazateli a hydromorfologickým ovlivněním. Zpracování dat pro reporting Evropské komisi může ČR pomoci uvědomit si všechny souvislosti a podle nich upravit některé postupy pro třetí cyklus plánů. 


\section{Literatura}

[1] WFD Reporting Guidance 2016. Final draft, version 6. 0. 6 [online]. WFD CIS (Water Framework Directive's Common Implementation Strategy), 2016, [cit. 7. února 2017]. Dostupné z: http://cdr.eionet europa.eu/help/WFD/WFD_521_2016

[2] MŽP. Metodika určeni silně ovlivněných vodních útvarü. Praha: MŽP, 2013.

[3] VÚV TGM. WFD reporting 2016. Praha: VÚV TGM, 2016.

[4] MKOL. Mezinárodní plán oblasti povodí Labe. Část A. Aktualizace 2015 na období 2016-2021.

[5] Směrnice Evropského parlamentu a Rady 2000/60/ES ze dne 23. řijna 2000 ustavující rámec pro činnost Společenství v oblasti vodní politiky.

[6] Směrnice Evropského parlamentu a Rady 91/271/EHS ze dne 21. května 2000 o čištění městských odpadních vod.

[7] Národní plán povodí Labe [online]. Ministerstvo zemědělství a Ministerstvo životního prostřed 2015, [cit. 7. února 2017]. Dostupné z: http://eagri.cz/public/web/mze/zivotni-prostredi/ochrana-vody/vodni-ramcova-smernice/planovani-v-oblasti-vod/priprava-planu-povodi-pro-2-obdobi/ narodni-plany-povodi

[8] Národní plán povodí Odry [online]. Ministerstvo zemědělství a Ministerstvo životního prostřed 2015, [cit. 7. února 2017]. Dostupné z: http://eagri.cz/public/web/mze/zivotni-prostredi/ochrana-vody/vodni-ramcova-smernice/planovani-v-oblasti-vod/priprava-planu-povodi-pro-2-obdobi/ narodni-plany-povodi

[9] Národní plán povodí Dunaje [online]. Ministerstvo zemědělstvía Ministerstvo životního prostředi 2015, [cit. 7. února 2017]. Dostupné z: http://eagri.cz/public/web/mze/zivotni-prostredi/ochrana-vody/vodni-ramcova-smernice/planovani-v-oblasti-vod/priprava-planu-povodi-pro-2-obdobi/ narodni-plany-povodi

\section{Autoři}

RNDr. Hana Prchalová

凶hana.prchalova@vuv.cz

Mgr. Silvie Semerádová

凶silvie.semeradova@vuv.cz

\section{Ing. Petr Vyskoč}

凶petr.vyskoc@vuv.cz

Výzkumný ústav vodohospodářský T. G. Masaryka, v. v. i.

Příspěvek prošel lektorským řízením.

\section{SELECTED RESULTS OF REPORTED RIVER BASIN MANAGEMENT PLANS IN THE CZECH REPUBLIC}

\section{PRCHALOVA, H.; SEMERADOVA, S.; VYSKOC, P.}

TGM Water Research Institute, p. r. i.

Keywords: Water Framework Directive - River Basin Management Plan water status - water body - programme of measures impacts and pressures analysis

River Basin Management Plans data processing enables obtain not only detailed summary of results, but also appreciates relations between partial results and their significance to achievement of specified objectives. The article is focused on selected results not recognized as priority ones. These results are water use of heavily modified water bodies, harmonisation of biological elements and general physico-chemical substances boundaries of good ecological status, identification of significant anthropogenic pressures, responsible for not achieving good status and cost of measures allocation. It is not possible to underestimate these relations due to an adequate efficiency of financial and time sources. 